\title{
Corporate Social Responsibility Policy And Brand Value
}

\author{
Omar Farooq, Ph.D., American University, Egypt \\ Samir Aguenaou, Ph.D., Al Akhawayn University, Morocco \\ Mohamed Amine Amor, Ph.D., Al Akhawayn University, Morocco
}

\begin{abstract}
In this paper, we document that corporate social responsibility (CSR) has a negative effect on brand value. Our results show that this negative relationship exists only in firms where investor interest and visibility is high. We show that the negative impact of CSR policies is experienced by firms with high analyst following, larger size, and high earnings. We argue that markets consider CSR activities as a form of corporate charity with no expectations of positive returns. As a result, CSR activities are unnecessary costs incurred by firms. These costs result is adversely affecting current and expected financial performances. Given that current and expected financial performances are important determinants of brand value, firms with more visible CSR activities experience decline in brand values. We also show that certain components of CSR policy - firms who audit their CSR report from external auditors, brands of firms who report their global CSR activities, and brands of firms who publish a separate CSR report-exert more negative influence on brand values than the other components. All of these components are also related to increasing visibility of CSR activities.
\end{abstract}

Keywords: Corporate Social Responsibility; CSR; Brand Value; Reputation

\section{INTRODUCTION}

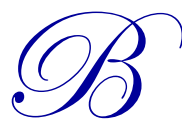

rands are intangible assets that induce customers to develop long-term relationships with firms (Park et al., 2010; Schau et al., 2009). Long-term relationships, eventually, translate into increased revenues, lower customer price sensitivity, and reduced marketing costs (Ailawadi et al., 2003; Mizik and Jacobson, 2008). As a result, it is argued that firms with stronger brands have more sustainable and superior performance. Given the importance of brand for firm performance, prior literature has identified several factors, financial as well as non-financial, that can help firms improve the value of their brands. Simon and Sullivan (1993), for instance, propose that there is a positive relationship between brand value and financial indicators of firms. While, Keller (2003) argues that marketing programs are significant determinant of brand values. However, an important factor that has not received enough attention is the impact that socially responsible corporate actions have on the brand values. Socially responsible corporate actions or corporate social responsibility (hereafter CSR) is a corporate objective that may obligate firms to take into consideration the interests of society while making any decision. The CSR enables firms to voluntarily take those actions that go beyond statutory obligations to benefit the society (Martin, 2008). The focus of CSR is, therefore, not solely only profit maximization.

In this paper, we hypothesize that the CSR policies adopted by firms have a significant impact on brand values. We argue that the CSR policies can affect brand values via their impact on: (1) Current financial performance of branded items, (2) Brand loyalty of the customers, and (3) Ability to deliver favorable future financial performance. ${ }^{1}$

${ }^{1}$ All of these factors are also the basic inputs to the way brand value is computed for this study. 
- $\quad$ The relationship between the CSR policies and brand value seems natural because the CSR is an important tool via which firms can build their reputation in the society. Much of prior literature considers embracing the CSR standards, philanthropic giving, and development of trusting relationships with society as the main antecedents of reputation (Fombrun, 2005; Brammer and Millington, 2005; MacMillan et al., 2004). Firms that neglect the consequence of their actions on society expose themselves to the risk of losing reputation and trust among customers. Loss of reputation (or even a weaker reputation) can adversely impact firm performance. Stuebs and Sun (2011) argue that firms with weaker CSR practices face more labor problems, more complaints from community, and more environmental concerns from the government. Consequently, weaker CSR practices translate into adverse firm performance (Beurden and Gossling, 2008). ${ }^{2}$ Becchetti et al. (2013) document a significant negative effect on returns after exit announcements from the CSR index. Given that firm performance is an important input for brand value, we hypothesize that stronger brands should have more favorable CSR policies.

- $\quad$ Another argument cited to relate CSR policies with brand value is the impact of CSR on brand preference, brand loyalty and positive word-of-mouth (Rust et al., 2000; Holt et al., 2004). Du et al. (2007) report that favorable CSR policies lead to stronger brand identification, brand loyalty, and brand advocacy. Therefore, we argue that favorable CSR policies translate into increased commitment from customers and other stakeholders towards a firm. As a result, we hypothesize a positive relationship between brand value and the CSR policies.

- $\quad$ Vlachos et al. (2009) documents an association between the CSR policies and repeat patronage intentions of customers. We argue that this type of customer loyalty ensures that financial performance in the future will be up to the expectations. Furthermore, Dowling (2001) argues that reputational capital associated with favorable CSR policies can help insulate firms from turbulent times. He notes that reputation acts as a buffer and protects firms from the impact of tough economic times. Given that the ability to deliver adequate performance in future is an important determinant of brand value, we hypothesize a positive relationship between brand value and the CSR policies.

Consistent with our arguments above, prior literature also shows a positive impact of CSR policies on brand values (Beurden and Gossling, 2008; Sanchez and Sotorrio, 2007; Margolis and Walsh, 2003; Orlitzky et al., 2003). Brickley et al. (2002), for example, show that more socially responsible a firm's behavior is, more valuable is the brand. In another related study, Torres et al. (2012) consider CSR as one of the most important factors for achieving sustained brand equity. However, in contrast with above arguments, our results show a significant and a negative relationship between CSR policies and brand value. We argue that the negative relationship observed in this paper may be due to managerial opportunism. Preston and O'Bannon (1997) argue that managers can reduce investment in socially responsible activities to boost short-term profits (probably to increase their compensation/bonuses). Our result may also be due to the fact that socially responsible firms have competitive disadvantage in a way that they have unnecessary costs. Waddock and Graves (1997) argue that CSR related costs reduce shareholders profits and wealth. Campbell (2007) also assumes that CSR activities are akin to a form of corporate charity. These are the activities that are undertaken by firms without any expectations of positive economic returns. Given that current and future financial performance is an important determinant of brand value, brands of socially responsible firms tend to underperform brands of other firms.

Furthermore, our results show that negative relationship between CSR policies and brand value is experienced only in firms with high visibility and investor interest. For example, we show that for any given level of CSR policy, higher analyst following result in lower brand value. Similar results are obtained when we use size and earnings per share as the proxy for high visibility and investor interest. Our results also show that certain components of CSR policy exert more influence on brand value than the other. We show that brands of firms who audit their CSR report from external auditors, brands of firms who report their global CSR activities, and brands of firms who publish a separate CSR report underperform other firms. It shows that greater disclosure of CSR activities is not valued by the market. These findings support Campbell (2007) and Waddock and Graves (1997) who consider CSR activities as corporate charity without any expectation of positive returns.

\footnotetext{
${ }^{2}$ Barnett and Salomon (2006) suggest that increasing numbers of investors have started to value the way corporations meet their social responsibilities. Increased attention in CSR should also translate into stronger impact of CSR on firm performance.
} 
The remainder of the paper summarizes the data, assesses of our hypothesis, discusses our results, and presents our conclusions.

\section{DATA}

This paper documents the relationship between corporate social responsibility and brand performance. The period under study is between 2002 and 2010. Following sub-sections will describe the data in detail.

\section{Brand Performance}

The data for brand performance is provided by Interbrand. The method adopted by Interbrand considers the ongoing investment and management of the brand as a business asset. According to Interbrand, their methodology takes into account all of the ways in which a brand touches and benefits its organization - from attracting and retaining talent to delivering on customer expectations. Interbrand takes into consideration the following three factors while making their assessment regarding the brand value:

- Financial performance of the branded products or services: This factor measures an organization's raw financial return to investors.

- Role of brand in the purchase decision process: This factor measures the portion of the decision to purchase that is attributable to brand. An important point to mention here is that role of brand in the purchase decision is exclusive of other aspects of the offer like price or feature of the product. Conceptually, this factor reflects the portion of demand for a branded product or service that exceeds what the demand would be for the same product or service if it were unbranded.

- Strength of the brand: This factor measures the ability of the brand to secure the delivery of expected future earnings.

Interbrand uses the above factors to come up with a dollar value of the brand. We use the annual change in the dollar value of the brand (BRAND) as a measure of its performance over the year. Table 1 documents the descriptive statistics for the performance of brands during our sample period. Panel A documents average annual change in brand value for each year, while Panel B and Panel C shows similar statistics for each industry and each region, respectively. Our results in Table 1, Panel A, show that brand performance was worst during 2002 and 2009. During these years, we document significantly negative performance of brands. Our results show that brand values declined by 0.2416 basis points and 0.0597 basis points, respectively during these years. The best performance of brands was observed in 2006. The brand values experienced a significant increase of 0.0676 basis points during 2006. Table 1, Panel B, shows that brands belonging to Financial Services and Diversified Industries did not perform well during our sample period. We report no significant change in brand values for firms belonging to these sectors. The best performance of brands was observed by firms belonging to Business Services. In this sector, the brand values experienced a significant increase of 0.0485 basis points during our sample period. Furthermore, Table 1, Panel C, shows that the brands belonging to the United States underperformed the brands belonging to other countries. 
Table 1. Descriptive statistics for brand performance

Panel A. Average change in brand value for each year

\begin{tabular}{lcc}
\hline \multicolumn{1}{c}{ Year } & Mean & No. of Observations \\
\hline 2002 & $-0.2416^{*}$ & 41 \\
2003 & $0.0215^{* *}$ & 46 \\
2004 & $0.0396^{* * *}$ & 51 \\
2005 & 0.0235 & 60 \\
2006 & $0.0676^{* * *}$ & 59 \\
2007 & $0.0622^{* * *}$ & 44 \\
2008 & $0.0289^{* * *}$ & 57 \\
2009 & $-0.0597^{* * *}$ & 49 \\
$2010 \quad 0.03586^{*}$ & 29 \\
\hline Panel B. Average change in brand value for each industry & No. of Observations \\
\hline \multicolumn{1}{c}{ Industry } & Mean & 63 \\
\hline Business Services & $0.0485^{* * *}$ & 112 \\
Consumer Goods & $0.0263^{* *}$ & 71 \\
Diversified Industries & -0.0049 & 81 \\
Electronics Country & $0.0264^{* *}$ & 54 \\
Financial Services & 0.0072 & 55 \\
Miscellaneous & $0.0314^{* * *}$ & \\
\hline Panel C. Average change in brand value for each region & & 175 \\
\hline \multicolumn{1}{c}{ Mean } & 261 \\
\hline Others & $0.0255^{* * *}$ & No. of Observations \\
\hline United States of America & $0.0208^{* * *}$ & \\
\hline
\end{tabular}

Note: The values with $1 \%$ significance are followed by ***, values with $5 \%$ by **, and values with $10 \%$ by .

\section{Corporate Social Responsibility Index}

This paper uses the following questions to construct an index representing the corporate social responsibility of a firm.

- (Q1) Does the company have a policy to maintain an effective and independent CSR committee?

- $\quad$ (Q2) Does the company have a CSR committee?

- $\quad$ (Q3) Does the company have an external auditor of its CSR report?

- $\quad(\mathrm{Q} 4)$ Does the company report on belonging to a specific CSR index?

- (Q5) Does the company's extra-financial report take into account the global CSR activities of the company?

- (Q6) Does the company publish a separate CSR report or publish a section in its annual report on CSR?

The questions capture various aspects of a firm's policies and practices that constitute good corporate social responsibility. A total score for each firm for which data for all six criteria is available is calculated each year. Each question is constructed in a manner that the answer 'yes' adds one point to the CSR score. Thus, the rating is on a scale of zero to six, with a higher score indicating better CSR practice. All of the information is collected from the datastream.

The descriptive statistics of the CSR index are reported in Table 2. Panel A documents average annual change in brand value for each year, while Panel B and Panel C shows similar statistics for each industry and each region, respectively. The results in Table 2, Panel A, show that CSR practices gradually improved from 2002 to 2010. The lowest value of CSR index is observed in 2002, while the highest values of CSR index is observed in 2010. Results of this Panel A indicate that CSR has become more important to firms in recent years. Table 2, Panel B, shows that firms belonging to Financial Services and Diversified Industries have the best CSR practices. We report highest value of CSR index for firms belonging to these sectors. Table 2, Panel B, also report that firms belonging to Business Services have the worst CSR practices. Surprisingly, our results in Table 2, Panel C, show that brands belonging to the United States do not have as good CSR practices as the brands belonging to other countries. We report lower value of CSR index for brands belonging to the United States. 
Table 2. Descriptive statistics for CSR index

Panel A. Average CSR index for each year

\begin{tabular}{|c|c|c|c|}
\hline Year & Mean & Median & Standard Deviation \\
\hline 2002 & 1.0652 & 1.0000 & 1.2543 \\
\hline 2003 & 1.2500 & 1.0000 & 1.2964 \\
\hline 2004 & 1.5964 & 2.0000 & 1.5101 \\
\hline 2005 & 1.7343 & 1.0000 & 1.6158 \\
\hline 2006 & 2.2542 & 2.0000 & 1.8808 \\
\hline 2007 & 3.9574 & 4.0000 & 1.7062 \\
\hline 2008 & 4.2542 & 5.0000 & 1.4573 \\
\hline 2009 & 4.6938 & 5.0000 & 1.1031 \\
\hline 2010 & 5.2187 & 5.5000 & 0.9749 \\
\hline
\end{tabular}

Panel B. Average CSR index for each industry

\begin{tabular}{lccc}
\hline \multicolumn{1}{c}{ Industry } & Mean & Median & Standard Deviation \\
\hline Business Services & 1.6617 & 0.0000 & 2.0267 \\
Consumer Goods & 2.7118 & 3.0000 & 2.0635 \\
Diversified Industries & 3.1750 & 3.0000 & 2.1095 \\
Electronics & 2.4883 & 2.0000 & 1.8002 \\
Financial Services & 3.2063 & 4.0000 & 2.0647 \\
Miscellaneous & 2.9508 & 3.0000 & 2.1635 \\
\hline
\end{tabular}

Panel C. Average CSR index for each region

\begin{tabular}{lccc}
\hline \multicolumn{1}{c}{ Country } & Mean & Median & Standard Deviation \\
\hline Others & 3.3350 & 4.0000 & 1.9781 \\
United States of America & 2.2553 & 2.0000 & 2.0419 \\
\hline
\end{tabular}

\section{Control Variables}

This paper uses a number of firm-specific characteristics, such as log of total assets (SIZE), total debt to total asset ratio (LEVERAGE), dividend payout ratio (PoR), earnings per share (EPS), and analyst following (ANALYST) as control variables. We obtain date for the above mentioned variables from the Worldscope. Table 3 documents the statistics for our control variables during our sample period. Panel A documents descriptive statistics for the control variables used in our analysis and Panel B documents the correlation between different control variables. An interesting observation in Table 3, Panel A, is that firms in our sample pay very low amount of their earnings as dividends - only $29.49 \%$. It also shows that, on average, firms in our sample have very low amount of leverage - only $27.77 \%$. In addition, the results in Table 3, Panel B, show no severe multicollinearity between our control variables. Therefore, we can include all of the control variables together in our regression equations.

Table 3. Statistics for control variables

Panel A. Descriptive statistics for control variables

\begin{tabular}{lrrr}
\multicolumn{1}{c}{ Year } & Mean & Median & Standard Deviation \\
\hline SIZE & 18.2113 & 17.8600 & 1.8550 \\
LEVERAGE & 0.2477 & 0.2300 & 0.1724 \\
PoR & 29.4902 & 29.2500 & 21.5069 \\
EPS & 3.0589 & 1.9400 & 4.6890 \\
ANALYST & 24.9177 & 22.0000 & 9.0730 \\
\hline
\end{tabular}

$\underline{\text { Panel B. Correlation between control variables }}$

\begin{tabular}{|c|c|c|c|c|c|}
\hline & SIZE & LEVERAGE & PoR & EPS & ANALYST \\
\hline SIZE & 1.0000 & & & & \\
\hline LEVERAGE & -0.2113 & 1.0000 & & & \\
\hline PoR & 0.2266 & 0.1263 & 1.0000 & & \\
\hline EPS & 0.3065 & -0.0232 & 0.1365 & 1.0000 & \\
\hline ANALYST & 0.1900 & -0.4409 & -0.0413 & 0.0165 & 1.0000 \\
\hline
\end{tabular}




\section{METHODOLOGY}

This paper hypothesizes that brand performance is an increasing function of corporate social responsibility. In order to test this hypothesis, we estimate a regression equation with annual change in brand value (BRAND) as a dependent variable and an index representing the extent of corporate social responsibility (CSR) as an independent variable. For the purpose of completeness, we also include region dummies (RDUM), industry dummies (IDUM), and year dummies (YDUM) in our regression equation. It is important to mention here that we use panel data regression with fixed effects for our analysis. Hausman test was used to decide between fixed effect and random effects. Our basic regression takes the following form.

$$
\begin{aligned}
& \text { BRAND }=\alpha+\beta_{1}(\mathrm{CSR}) \\
& +\sum_{\text {Year }} \beta^{\text {Year }}(\text { YDUM })+\sum_{\text {Ind }} \beta^{\text {Ind }}(\text { IDUM })+\sum_{\text {Rg }} \beta^{\text {Rg }}(\text { RDUM })+\varepsilon
\end{aligned}
$$

However, there may be concerns that some of the firm-specific characteristics can affect the brand performance. In order to overcome these concerns, we complement Equation (1) by adding number of firm-specific variables that can affect brand value. For instance, earnings per share (EPS) and dividend payout ratio (PoR) are added to control for the effect of profitability on brand value. Profitable firms can spend more money on building their brands. Similarly, log of firm's total assets (SIZE) and number of analysts following a firm (ANALYST) are added to control for the effect of visibility and investor interest. Firms with more visibility and high investor interest can have higher brand value. We also add total debt to total asset (LEVERAGE) to control for the effect of risk on brand value. High leverage exposes firms to greater financial risk and therefore can negatively affect brand value. Our modified regression takes the following form.

$$
\begin{aligned}
& \text { BRAND }=\alpha+\beta_{1}(\mathrm{CSR}) \\
& +\beta_{2}(\mathrm{SIZE})+\beta_{3}(\text { LEVERAGE })+\beta_{4}(\mathrm{PoR})+\beta_{5}(\text { EPS })+\beta_{6}(\text { ANALYST }) \\
& +\sum_{\text {Year }} \beta^{\text {Year }}(\text { YDUM })+\sum_{\text {Ind }} \beta^{\text {Ind }}(\text { IDUM })+\sum_{\mathrm{Rg}} \beta^{\text {Rg }}(\text { RDUM })+\varepsilon
\end{aligned}
$$

The results of our analysis are reported in Table 4. The results of our analysis show a negative relationship between brand performance and corporate social responsibility. We report negative and significant coefficient of CSR. Our results show that for one unit increase in CSR index, brand value decreases by 0.0145 basis points. Our results are consistent with Campbell (2007) and Waddock and Graves (1997) who consider CSR activities as a form of corporate charity. Given that charity is done without expectations of positive returns, market considers these activities as unrelated costs. Therefore, CSR activities result adverse impact on brand values.

Table 4. Relationship between brand value and corporate social responsibility

\begin{tabular}{lcc}
\hline & Equation (1) & Equation (2) \\
\hline CSR & $-0.0124^{* * *}$ & $-0.0145^{* * *}$ \\
\hline SIZE & & 0.0424 \\
LEVERAGE & & 0.0150 \\
PoR & & -0.0005 \\
EPS & & 0.0073 \\
ANALYST & Yes & -0.0006 \\
\hline Industry Dummies & Yes & Yes \\
Year Dummies & Yes & Yes \\
Region Dummies & 436 & Yes \\
\hline No. Of Observations & 4.53 & 337 \\
F-Value & 0.0390 & 2.67 \\
$\mathrm{R}^{2}$ (within) & & 0.0908 \\
\hline
\end{tabular}

Note: The coefficients with $1 \%$ significance are followed by $* * *$, coefficient with $5 \%$ by $* *$, and coefficients with $10 \%$ by $*$.

There may be concerns that the results reported in Table 4 are confined to certain stocks. For instance, large firms have more visibility in the market. As a result, it is very much possible that corporate social responsibility practices get noticed in these firms more than the other firms. In firms with lower visibility, corporate social 
responsibility practices may remain unnoticed. In order to address these concerns, we divide our sample into two groups - first group containing firms with above average size and second group containing firms with below average size - and re-estimate Equation (2) for both groups. The results are reported in Table 5. Our results in Table 5 show that corporate social responsibility is a significant determinant of brand performance only for large firms. We report negative and significant coefficient of CSR for a sample comprising large firms. Interestingly, our results show insignificant relationship between corporate social responsibility and brand performance in a sample of small firms. The coefficient of CSR is insignificant for a sample of small firms.

Table 5. Relationship between brand value and corporate social responsibility for a sub-sample of large firms and for a sub-sample of small firms

\begin{tabular}{lcc}
\hline & Small Firms & Large Firms \\
\hline CSR & -0.0098 & $-0.0215^{* * *}$ \\
\hline SIZE & -0.0416 & $0.1777^{* *}$ \\
LEVERAGE & 0.0409 & $0.3716^{*}$ \\
PoR & $-0.0011^{*}$ & -0.0007 \\
EPS & $0.0189^{* *}$ & 0.0070 \\
ANALYST & 0.0009 & $-0.0039^{*}$ \\
\hline Industry Dummies & Yes & Yes \\
Year Dummies & Yes & Yes \\
Region Dummies & Yes & Yes \\
\hline No. Of Observations & 201 & 136 \\
F-Value & 3.06 & 3.45 \\
$\mathrm{R}^{2}$ (within) & 0.0934 & 0.2729 \\
\hline
\end{tabular}

Note: The coefficients with $1 \%$ significance are followed by ***, coefficient with $5 \%$ by $* *$, and coefficients with $10 \%$ by *.

\section{DISCUSSION OF RESULTS}

\section{What Determines the Negative Relationship Between Brand Performance and Corporate Social Responsibility?}

Table 5 indicates an insignificant relationship between brand performance and corporate social responsibility among small firms. Given that small firms are less visible, it is very much possible that visibility/investor interest in a firm determines the relationship between corporate social responsibility and brand performance. In order to test this conjecture, we estimate the following regression equations. In the following regressions, size (SIZE), analyst following (ANALYST), and earnings per share (EPS) are treated as a proxy for visibility/investor interest in a firm. If visibility/investor interest is a significant determinant of the relationship between corporate social responsibility and brand performance, we should expect coefficient of CSR to be insignificant and the coefficient of interaction term (CSR*SIZE, CSR*ANALYST, or CSR*EPS) to become significant. 


$$
\begin{aligned}
& \text { BRAND }=\alpha+\beta_{1}(\mathrm{CSR})+\beta_{2}(\text { ANALYST })+\beta_{3}(\mathrm{CSR} * \text { ANALYST }) \\
& \beta_{4}(\text { LEVERAGE })+\beta_{5}(\text { PoR })+\beta_{6}(\text { EPS })+\beta_{7}(\text { SIZE }) \\
& +\sum_{\text {Year }} \beta^{\text {Year }}(\text { YDUM })+\sum_{\text {Ind }} \beta^{\text {Ind }}(\text { IDUM })+\sum_{\text {Rg }} \beta^{\text {Rg }}(\text { RDUM })+\varepsilon
\end{aligned}
$$

And

$$
\begin{aligned}
& \text { BRAND }=\alpha+\beta_{1}(\mathrm{CSR})+\beta_{2}(\mathrm{SIZE})+\beta_{3}(\mathrm{CSR} * \mathrm{SIZE}) \\
& \beta_{4}(\mathrm{LEVERAGE})+\beta_{5}(\mathrm{PoR})+\beta_{6}(\mathrm{EPS})+\beta_{7}(\mathrm{ANALYST}) \\
& +\sum_{\text {Year }} \beta^{\text {Year }}(\text { YDUM })+\sum_{\text {Ind }} \beta^{\text {Ind }}(\mathrm{IDUM})+\sum_{\mathrm{Rg}} \beta^{\text {Rg }}(\mathrm{RDUM})+\varepsilon
\end{aligned}
$$

And

$$
\begin{aligned}
& \text { BRAND }=\alpha+\beta_{1}(\mathrm{CSR})+\beta_{2}(\mathrm{EPS})+\beta_{3}(\mathrm{CSR} * \text { EPS }) \\
& \beta_{4}(\text { LEVERAGE })+\beta_{5}(\mathrm{PoR})+\beta_{6}(\mathrm{SIZE})+\beta_{7}(\text { ANALYST }) \\
& +\sum_{\text {Year }} \beta^{\text {Year }}(\text { YDUM })+\sum_{\text {Ind }} \beta^{\text {Ind }}(\text { IDUM })+\sum_{\mathrm{Rg}} \beta^{\mathrm{Rg}}(\mathrm{RDUM})+\varepsilon
\end{aligned}
$$

Our results are reported in Table 6. Consistent with our conjecture, our results show insignificant impact of corporate social responsibility on brand performance. We report insignificant coefficient of CSR. However, we also show that negative impact of corporate social responsibility on brand performance is exercised via visibility/investor interest in a firm. Our results show significant and negative coefficients of CSR*SIZE, CSR*ANALYST, and CSR*EPS. Our results show that greater disclosure of CSR activities have adverse impact on brand values. As was mentioned above, it may be due to the fact that CSR activities are considered as a form of corporate charity without expectation of positive returns. As a result, CSR activities adversely impact financial performance, which eventually produce negative impact on brand values.

Table 6. Effect for visibility on the relationship between brand value and corporate social responsibility

\begin{tabular}{lccc}
\hline & Equation (3a) & Equation (3b) & Equation (3c) \\
\hline CSR & -0.0123 & 0.0069 & -0.0078 \\
ANALYST & -0.0012 & -0.0014 & -0.0011 \\
CSR*ANALYST & $-0.0246^{* *}$ & & 0.0357 \\
SIZE & 0.0414 & 0.0420 & \\
CSR*SIZE & & $-0.0348^{* * *}$ & $0.0171^{* * *}$ \\
EPS & 0.0078 & 0.0080 & $-0.0018^{*}$ \\
CSR*EPS & & & 0.0244 \\
LEVERAGE & 0.0195 & 0.0261 & -0.0005 \\
PoR & -0.0006 & -0.0006 & Yes \\
Industry Dummies & Yes & Yes & Yes \\
Year Dummies & Yes & Yes & Yes \\
Region Dummies & 337 & Yes & 337 \\
No. Of Observations & 3.10 & 337 & 5.04 \\
F-Value & 0.0819 & 3.06 & 0.0931 \\
R (within) & 0.0837 & \\
\hline Note: The coefficients
\end{tabular}

Note: The coefficients with $1 \%$ significance are followed by $* * *$, coefficient with $5 \%$ by **, and coefficients with $10 \%$ by $*$. 


\section{Which Component of Corporate Social Responsibility More Important for Brand Performance?}

In this section, we estimate the effect of individual components of corporate social responsibility on the performance of brands. The results of our analysis are reported in Table 6. Our results show that brands of firms who audit their CSR report from external auditors (Q3), brands of firms who report their global CSR activities (Q5), and brands of firms who publish a separate CSR report (Q6) underperform other firms. We report significant and negative coefficient of CSR when these variables are used as a proxy for corporate social responsibility in Table 7. These results support above findings because all of these factors are related to the quality of disclosure. As was indicated above, CSR activities are a form of corporate charity and market consider such activities as unnecessary cost, thereby resulting in a negative impact on firm performance. Given that current and future financial performance is an important determinant of brand value, brands of socially responsible firms tend to underperform brands of other firms.

Table 7. Relationship between brand value and individual components of corporate social responsibility

\begin{tabular}{|c|c|c|c|c|c|c|c|}
\hline CSR1 & -0.0076 & & & & & & 0.0073 \\
\hline CSR2 & & -0.0097 & & & & & 0.0176 \\
\hline CSR3 & & & $-0.0679 * * *$ & & & & $-0.0664 * * *$ \\
\hline CSR4 & & & & 0.0138 & & & 0.0302 \\
\hline CSR5 & & & & & $-0.0455 * * *$ & & $-0.0359 * *$ \\
\hline CSR6 & & & & & & $-0.0466 * * *$ & $-0.0410 * * *$ \\
\hline SIZE & 0.0248 & 0.0282 & 0.0306 & 0.0218 & 0.0229 & 0.0356 & 0.0283 \\
\hline LEVERAGE & -0.0155 & -0.0162 & 0.0354 & -0.0106 & 0.0004 & 0.0331 & 0.1040 \\
\hline PoR & -0.0007 & -0.0007 & $-0.0007 *$ & -0.0007 & -0.0006 & -0.0006 & -0.0007 \\
\hline EPS & 0.0079 & 0.0079 & 0.0073 & 0.0080 & 0.0078 & 0.0079 & 0.0075 \\
\hline ANALYST & -0.0012 & -0.0012 & -0.0007 & -0.0012 & -0.0012 & -0.0016 & $-0.0009 *$ \\
\hline $\begin{array}{l}\text { Industry } \\
\text { Dummies }\end{array}$ & Yes & Yes & Yes & Yes & Yes & Yes & Yes \\
\hline Year Dummies & Yes & Yes & Yes & Yes & Yes & Yes & Yes \\
\hline Region Dummies & Yes & Yes & Yes & Yes & Yes & Yes & Yes \\
\hline $\begin{array}{l}\text { No. Of } \\
\text { Observations }\end{array}$ & 337 & 337 & 337 & 337 & 337 & 337 & 337 \\
\hline F-Value & 2.65 & 2.59 & 6.24 & 3.22 & 2.69 & 3.57 & 4.33 \\
\hline $\mathrm{R}^{2}$ (within) & 0.0630 & 0.0636 & 0.0974 & 0.0643 & 0.0878 & 0.0836 & 0.1366 \\
\hline
\end{tabular}

Note: CSR1 corresponds to Q1 of Section 2.2, CSR2 corresponds to Q2 of Section 2.2, CSR3 corresponds to Q3 of Section 2.2, CSR4 corresponds to Q4 of Section 2.2, CSR5 corresponds to Q5 of Section 2.2, and CSR6 corresponds to Q6 of Section 2.2. The coefficients with $1 \%$ significance are followed by $* * *$, coefficient with $5 \%$ by **, and coefficients with $10 \%$ by $*$.

\section{CONCLUSION}

This paper documents the relationship between CSR policy and brand values. Surprisingly, we document a significant and a negative relationship between CSR policy and brand values. Our results are consistent with arguments that consider CSR activities as either the reasons for managerial opportunism or the source of corporate charity (Preston and O'Bannon, 1997; Waddock and Graves, 1997). Both of these factors lead to negative impact of CSR policy on brand values. Our results also show that our results show that negative relationship between CSR policies and brand value exists only in firms with high visibility and investor interest. We argue that CSR activities in firms with high visibility and investor interest get noticed quickly. Given that CSR activities may be considered as a form of corporate charity, high visibility leads to negative relationship between CSR policy and brand values. 


\section{AUTHORS' INFORMATION}

Omar Farooq, Ph.D., Department of Management, American University in Cairo, Cairo, Egypt. Correspondence Address: Department of Management, American University in Cairo, Cairo, Egypt.

Email: omar.farooq.awan@gmail.com

Samir Aguenaou, Ph.D., School of Business Administration, Al Akhawayn University in Ifrane, Ifrane, Morocco.

Mohamed Amine Amor, Ph.D., School of Business Administration, Al Akhawayn University in Ifrane, Ifrane, Morocco.

\section{REFERENCES}

Ailawadi, K. L., Lehmann, D. R., and Neslin, S. A., (2003). Revenue Premium as an Outcome Measure of Brand Equity. Journal of Marketing, 67, pp. 1-17.

Barnett, M. L. and Salomon, R. M., (2006). Beyond Dichotomy: The Curvilinear Relationship between Social Responsibility and Financial Performance. Strategic Management Review, 27(11), pp. 1101-1156.

Becchetti, L., Ciciretti, R., Hasan, I., and Kobeissi, N., (2013). Corporate Social Responsibility and Shareholder's Value. Journal of Business Reseach, 65(11), pp. 1628-1635.

Beurden, P. and Gössling, T., (2008). The Worth of Values - A Literature Review on the Relation between Corporate Social and Financial Performance. Journal of Business Ethics, 82(2), pp. 407-424.

Brammer, S. and Millington, A., (2005). Corporate Reputation and Philanthropy: An Empirical Analysis. Journal of Business Ethics, 61(1), pp. 29-44.

Brickley, J., Smith, C., and Zimmerman, J., (2002). Business Ethics and Organizational Architecture. Journal of Banking and Finance, 26(9), pp. 1821-1835.

Campbell, J. L., (2007). Why would Corporations Behave in Socially Responsible Ways? An Institutional Theory of Corporate Social Responsibility. Academy of Management Review, 32(3), pp. 946-967.

Dowling, G. R., (2001). Creating Corporate Reputations. (Oxford, Oxford University Press).

Du, S., Bhattacharya, C. B., and Sen, S., (2007). Reaping Relational Rewards from Corporate Social Responsibility: The Role of Competitive Positioning. International Journal of Research in Marketing, 24, pp. 224-241.

Fombrun, C. J., (2005). Building Corporate Reputation through CSR Initiatives: Evolving Standards. Corporate Reputation Review, 8(1), pp. 54-68.

Holt, D. B., Quelch, J. A., and Taylor, E. L., (2004). How Global Brands Compete. Harvard Business Review, 82(9), 68-75.

Keller, K. L., (2003). Brand Synthesis: The Multidimensionality of Brand Knowledge. Journal of Consumer Research, 29, pp. 595-600.

MacMillan, K., Money, K., Downing, S., and Hillenbrand, C., (2004). Giving Your Organization SPIRIT: An Overview and Call to Action for Directors on Issues of Corporate Governance, Corporate Reputation and Corporate Responsibility. Journal of General Management, 30(2), pp. 15-42.

Margolis, J. D. and Walsh, J. P., (2003). Misery Loves Companies: Rethinking Social Initiatives by Business. Administrative Science Quarterly, 48(2), pp. 268-305.

Mizik, N. and Jacobson, R., (2008). The Financial Value Impact of Perceptual Brand Attributes.

Journal of Marketing Research, 44, pp. 15-32.

Orlitzky, M., Schmidt, F. L., and Rynes, S. L., (2003). Corporate Social and Financial Performance: A Metaanalysis. Organization Studies, 24(3), pp. 403-441.

Park, C. W., MacInnis, D. J., Priester, J., Eisingerich, A. B., and Iacobucci, D., (2010). Brand Attachment and Brand Attitude Strength: Conceptual and Empirical Differentiation of two Critical Brand Equity Drivers. Journal of Marketing, 74, pp. 1-18.

Preston, L. E. and O'Bannon, D. P., (1997). The Corporate Social-financial Performance Relationship: A Typology and Analysis. Business and Society, 36(4), pp. 419-429.

Rust, R. T., Zeithaml, V. A., and Lemon, K. N., (2000). Driving Customer Equity. NY: Free Press.

Sanchez, J. and L. Sotorrio, (2007). The Creation of Value through Corporate Reputation. Journal of Business Ethics 76(3), pp. 335-346.

Schau, H. J., Muñiz, A. M., Jr., and Arnould, E. J., (2009). How Brand Community Practices Create Value. Journal of Marketing, 73, pp. 30-51. 
Simon, C. J. and Sullivan, M. W., (1993). The Measurement and Determinants of Brand Equity: A Financial Approach. Marketing Science, 12(1), pp. 28-52.

Stuebs, M. and and Sun, L., (2011). Corporate Social Responsibility and Firm Reputation. Working Paper, Hankamer School of Business, Baylor University.

Torres, A., Bijmolt, T. H. A., Tribo, J, A., and Verhoef, P., (2012). Generating Global Brand Equity through Corporate Social Responsibility to Key Stakeholders. International Journal of Research in Marketing, 29(1), pp.13-24.

Vlachos, P. A., Tsamakos, A., Vrechopoulos, A. P., and Avramidis, P. K., (2009). Corporate Social Responsibility: Attributions, Loyalty, and the Mediating Role of Trust. Journal of the Academy of Marketing Science, 37(2), pp. 170-180.

Waddock, S. and Graves, S., (1997). The Corporate Social Performance-Financial Performance Link. Strategic Management Journal, 18(4), pp. 303-319. 


\section{NOTES}

